\title{
Die Fragilität des Zugangs
}

\section{Eine Kritik der Informationsgesellschaft}

„hoi mē eidotes, oiomenoi d' eidenai [...]. Hautē ara hē agnoia tōn kakōn aitia“.

(Platon, Alkibiades I 118a; 4. Jh. v. Chr.)

„Plato was the child of a time which is still our own.“

(Karl Popper, The Open Society and Its Enemies, 186; 1945)

„Wenn ein Löwe sprechen könnte, wir könnten ihn nicht verstehen.“

(Ludwig Wittgenstein, Philosophische Untersuchungen, 568; 1953)

„Niemand, der nicht fähig ist, mit sich selbst einen Dialog zu führen, kann sein Gewissen bewahren.“

(Hannah Arendt, Sokrates, 63; 1954)

„Wer einen Text verstehen will, ist vielmehr bereit, sich von ihm etwas sagen zu lassen.“ (Hans-Georg Gadamer, Wahrheit und Methode, 273; 1960)

„La liberté consiste à savoir que la liberté est en péril.“

(Emmanuel Levinas, Totalité et infini, 23; 1961)

„le temps du dialogue vivant est infini“.

(Jean-François Lyotard, Le Différend, 44; 1983)

„Parler la même langue, ce n'est pas seulement une opération linguistique.“

(Jacques Derrida, De l'Hospitalité, 117; 1997)

„Nous sommes structurellement des survivants“.

(Jacques Derrida, Apprendre à vivre enfin, 54; 2005)

„The hope of harmony in the contemporary world lies to a great extent in a clearer understanding of the pluralities of human identity“.

(Amartya Sen, Identity and Violence, xiv; 2006)

„It's hard to be an individual, to be conscious and alive inside the prison walls of your skull. So much easier to lay all that aside, to flow into something larger than yourself. So much easier to forget.“

(Hari Kunzru, Memory Palace, 15; 2013)

„La transparence n'est pas la vérité.“

(Anne Dufourmantelle, Défense du secret, 103; 2015) 

Meiner Familie

Meinen ersten Leser/inne/n danke ich für ihre Zeit und ihre Hilfe. 
